\title{
Bacteriological Assessment of Soil Contaminated with Cement Dust
}

\author{
Israel Obaroh $^{1,}$, , Tajudeen Yahaya ${ }^{2}$, Umar Ibrahim ${ }^{1}$ \\ ${ }^{1}$ Department of Biological Sciences Kebbi State University of Science and Technology, Aliero, Nigeria \\ ${ }^{2}$ Department of Biology, Federal University Birnin, Kebbi, Nigeria
}

Email address:

obarohio@gmail.com (I. Obaroh)

${ }^{*}$ Corresponding author

\section{To cite this article:}

Israel Obaroh, Tajudeen Yahaya, Umar Ibrahim. Bacteriological Assessment of Soil Contaminated with Cement Dust. Frontiers in Environmental Microbiology. Vol. 2, No. 3, 2016, pp. 14-17. doi: 10.11648/j.fem.20160203.11

Received: September 5, 2016; Accepted: October 12, 2016; Published: October 28, 2016

\begin{abstract}
The bacterial population and diversity in soil around a cement plant were assessed at two different sites. Site A (test site) was covered with cement dust, while site B (control site) was free of cement dust. Four soil samples were collected from the surface and below the surface at both sites and their bacterial density and diversity quantified. The bacteriological assessment were carried out using standard methods of analyses. The highest bacterial count of $209.33 \times 10^{4}$ was observed in surface soil sample in site B, while the least count of $66.00 \times 10^{4}$ was observed in soil sample obtained below the surface at site A. A total of 12 bacterial isolates were characterized which include; Micrococcus species, Kleibsella oxytoca, Clustridium species, Proteus mirabilis, Enterobacter cloacae, Citrobacter species, Cryseobacterium meningosepticum, Pseudomonas species, Klebsiella ornithinolytica, Pantoea, Acinobacter baumanii, and Serratia liquefaciens. Seven species were Gramnegative bacterial isolates there are; Proteus mirabilis, Enterobacter cloacae, Citrobacter species, Pseudomonas species, Klebsiella ornithinolytica, Pantoea species, Serratia liquefaciens, while five species were Gram-positive bacteria isolates, which includes; Micrococcus species, Klebsiella oxytoca, Clustridium species, Cryseobacterium meningosepticum, Acinobacter baumanii. These results showed that cement dust can reduce the abundance and diversity of soil bacteria. Therefore, there is a need to put in place appropriate pollution prevention and control strategies in the cement plant.
\end{abstract}

Keywords: Cement, Soil, Dust, Bacterial

\section{Introduction}

The word soil is used to denote the outer loose materials of the earth surface, it is formed as a result of rock weathering. Soil is rich in organic matter and so it provides an excellent media for the growth of many organisms including bacteria, fungi, actinomycetes, algae and protozoa. In ecology, soil is an active habitat especially for biological interactions [1].

Soil is composed of five major components: mineral matter, water, air, organic matter and living organisms. The quantity of these constituents is not the same in all soils, it varies from locality to locality. The soil is full of microorganisms, but their abundance and diversity can be reduced by inorganic matter content. This is because inorganic matter influences nutrient availability, aeration, and water retention [1].
Many microorganisms contribute to soil fertility and man depends on soil for cultivation. However, bacteria are the most abundant and beneficial when compared with other soil microorganisms [2]. The most common soil bacteria belong to the genera Pseudomonas, Arthrobacter, Clostridium Achromobacter, Sarcina, Enterobacter. Another group of bacteria common in soils is the Myxobacteria belonging to the genera Micrococcus, Chondrococcus, Archangium, Polyangium, Cyptophaga [3].

Bacteria bring about a number of changes and biochemical transformations in the soil and thereby directly or indirectly help in the nutrition of higher plants growing in the soil [1, 4]. Some of the important transformations and processes in which soil bacteria play vital roles include; decomposition of cellulose and other carbohydrates, ammonification (proteins ammonia), nitrification (ammonia-nitrites-nitrates), and denitrification (release of free elemental nitrogen). Others 
include biological fixation of atmospheric nitrogen (symbiotic and non-symbiotic) oxidation and reduction of sulphur and iron compounds, all these processes play a significant role in plant nutrition [3].

Soil microorganisms can destroy pollutants, but pollutants can also destroy the microbial succession or inhibit some varieties of microorganisms. Pollutants can also promote the growth of some destructive microorganisms, and these often lead to development of resistance of the soil ecosystem as a whole [5]. The production of cement is associated with the release of dust into the environment which subsequently settles on soils [6]. The major pollutants from cement production process are the alkaline particulates from the raw and finished materials [7, 8]. Thus the direct effects of cement dust pollution are alkalization of the ecosystem and the alteration of the soil chemical composition and though some of the heavy metals in cement dust like copper, zinc, manganese and iron are important for the growth of microorganism, however when in excess they become lethal to the microorganism $[8,9]$. Therefore, this study was carried out to assess the impact of cement dust pollution on the abundance and diversity of soil bacteria around a cement plant.

\section{Materials and Methods}

\subsection{Description of Study Area}

Cement Company of Northern Nigeria PLC (CCNN) popularly known as Sokoto Cement Company was founded by the premier of the Northern Region, Alhaji Sir Ahmadu Bello. It was strategically located in the South-Western axis of Sokoto city, about $5 \mathrm{~km}$ away from the city on latitude $13.1639^{\circ} \mathrm{N}$ and longitude $5.2218^{0} \mathrm{E}$. Sokoto cement was incorporated in 1962 and commenced production in 1967 with an initial installed capacity of 100,000 tons per annum, at Kalambaina plant. In order to meet the increasing demand for cement, a second plant with an installed capacity of 500,000 tons per annum was commissioned in 1985. However, the first plant was shut down in 1986 due to its poor economic output, thus leaving the company with a rated output of 500,000 tons per annum [10].

\subsection{Soil Sampling and Experimental Design}

The study commenced in April 2015 with the collection of soil samples at two different locations around the cement plant. A sample was collected in farmland (covered with cement dust) next to the company's fence (Site A) and the other about $10 \mathrm{~km}$ away from the factory towards the eastern part (Site B). At both locations, samples were collected from top soil and below the surface soil, about $5-10 \mathrm{~cm}$. The samples were collected in clean polythene bags and then transported to the laboratory for analysis.

\subsection{Soil Preparation and Analyses for Bacteria}

The soil samples were sieved to remove large pieces of debris and particles. Serial dilutions were carried out by measuring $1 \mathrm{~g}$ soil from each sample with a sterile spatula into a four $250 \mathrm{ml}$ beaker under normal atmospheric condition. Thereafter, $10 \mathrm{ml}$ of sterile water was introduced into each beaker and the soil suspension was stirred gently for 3 minutes to obtain a homogenized solution. Nine milliliter $(9 \mathrm{ml})$ of sterile distilled water was later measured into 10 labeled test tubes in a test tube rack. Afterward, $1 \mathrm{ml}$ was measured from the stock solution and dispensed into the first test tube labeled $\left(10^{-1}\right)$. From the first test tube, $1 \mathrm{ml}$ was introduced into the second test tube labeled $\left(10^{-2}\right)$, and continuously up to the last test tube label $\left(10^{-10}\right)$. The samples were cultured by using spread soil dilution plate method. Each dilution of the series (Nutrient agar, $\mathrm{pH}$ 7.2) was prepared and $20 \mathrm{ml}$ was placed onto petri-dishes containing nutrient agar and incubation at $37^{\circ} \mathrm{C}$ for $24-\mathrm{hrs}$. After the incubation, the average colony forming units (CFU) per gram of soil from three different plates were calculated [11].

\subsection{Isolation and Identification of Bacteria}

To obtain pure cultures, colonies of bacteria which varied in shaped and color were picked up and purified by streaking fresh on nutrient agar and incubated at $37^{\circ} \mathrm{C}$ for $24 \mathrm{hrs}$. The bacterial isolates were identified by Gram staining and other characteristics on the basis of classification schemes published in Bergey's Manual of Systematic Bacteriology [12].

\subsection{Biochemical Characterization of Microorganisms}

Bacteria isolated were characterized using some biochemical tests which included catalase, methyl red, Voges proskauer (MR-VP), nitrate reduction test and starch hydrolysis. Other tests used are gelatin liquefaction test, coagulase, indole, motility, oxidase, urease, triple sugar iron agar (TSI) and sugar fermentation as described by various authors $[13,14]$.

MR-VP Test

In this test, $10 \mathrm{ml}$ of MR-VP medium in a test tube was inoculated with the test organism and incubated at $35^{\circ} \mathrm{C}$ for twenty four to twenty eight (24-48) hours. Five drops of methyl red indicator solution was later added to $5 \mathrm{ml}$ of the culture. The appearance of red colour indicates the positive methyl red test, while yellow colour represents a negative test. To the remaining $5 \mathrm{ml}$ of the culture, $0.6 \mathrm{ml}$ of napthol solution and $0.2 \mathrm{ml}$ of $40 \%$ potassium hydroxide solution was added and kept for 2 to 4 hours. The appearance of red color indicated the positive VP test (Voges proskauer test), while yellow indicated negative test [13].

Catalase Test

A drop of $3 \%$ to $6 \%$ hydrogen peroxide was placed on a glass slide. Then a bit of growth of an isolate was picked with a wire loop and mixed with the drop of hydrogen peroxide on a glass slide. The formation of bubbles within seconds with pinkish red color appearance represents a positive test for urea utilization. No color change (yellow) indicated negative test $[13,14]$.

Citrate Utilization Test 
The test organism was inoculated on a Simmons citrate agar (SCA) slant with a sterile wire loop. The tube was inoculated at $35^{\circ} \mathrm{C}$ for twenty four to twenty forty eight (24-48) hours before examination. The presence of a blue colour indicated a positive test for citrate utilization, while the absence of growth and a green colour indicated negative test $[13,14]$.

Indole Test

One percent $(1 \%)$ tryptophan broth in a test tube was inoculated with a bacteria colony. After incubation period of $37^{\circ} \mathrm{C}$ for 48 hours, $1 \mathrm{ml}$ of chloroform was added to the broth. The test tube was shaken gently, after which $2 \mathrm{ml}$ of Kovac's reagent was added. Again, the test tube was shaken gently and allowed to stand for twenty (20) minutes. The formation of red colour at the top layer means positive while yellow coloration means negative test $[13,14]$.

Triple-Sugar Iron Agar Test (TSI)

The medium contains three (3) sugars namely: glucose, lactose and sucrose. The PH indicator is phenol red, and detection system for hydrogen suphide $\left(\mathrm{H}_{2} \mathrm{~S}\right)$ is included.

This medium was prepared as agar slope and the test organism was inoculated by stabbing the medium with the aid of sterilized straight wire loop. The surface of the slope is inoculated by streaking and then incubated at $37^{\circ} \mathrm{C}$ for 24 hours, after which observation was made.

Gas production was determined by cracking of the medium. The formation of $\mathrm{H}_{2} \mathrm{~S}$ was determined by the blackening of the whole buffer or a streak of ring of blackening at the slant butt junction. Glucose fermentation was determined by the yellowing of the butt. The fermentation of lactose or sucrose or both was determined by the yellowing of both the bottom and the slant. The motility was determined by observing the line inoculation; sharply defined line of inoculation indicated positive motility [14].

Urease Test

A colony of the test organisms was cultured in a urea agar slant in a bijou bottle and incubated for 24hours. The development of a bright pink colour indicates a positive result. The confirmed test organisms were sub-cultured on a nutrient agar slant in a bijou bottle and kept refrigerated [13, 14].

Coagulase Test

This was done to identify the Staphylococcus aureus. In this test, two drops of physiological saline were dropped in a glass slide, separated $2 \mathrm{~cm}$ apart by a mark on the glass slide. A colony of the organism was emulsified in each of the drops to make two thick suspensions. A loopful of little citrated human plasma was added to one of the bacterial suspension and mixed with the loop. The slide was held up and a little back and forth for a minute and clumping of the cells was observed [14].

\subsection{Statistical Analyses}

Analysis of variance (ANOVA) was used for test of significance among the four different sampling points. The difference among treatment means were separated using Duncan new multiple range test using SPSS statistical package.

\section{Results}

\subsection{Bacterial Load in Soil Sample}

As shown in Table 1, the highest bacterial load was observed in the control $\mathrm{B}_{1}$ (Surface soil) with $209.33 \times 10^{4}$ while the least was observed in $\mathrm{A}_{2}$ (Site A $5 \mathrm{~cm}$ below surface soil) with bacterial load of $66.00 \times 10^{4}$. The result showed significant difference among the means of all the isolates.

Table 1. Bacterial Count in Soil Samples.

\begin{tabular}{ll}
\hline Sample & Mean CFU/gm $(\mathbf{x ~ 1 0})$ \\
\hline Polluted $A_{1}$ (surface soil) & $84.00 \pm 12.00^{\mathrm{c}}$ \\
Polluted $\mathrm{A}_{2}(5 \mathrm{~cm}$ below surface soil) & $66.00 \pm 2.83^{\mathrm{c}}$ \\
Control $\mathrm{B}_{1}$ (surface soil) & $209.33 \pm 24.44^{\mathrm{a}}$ \\
Control $\mathrm{B}_{2}$ (5cm below surface soil) & $157.33 \pm 14.05^{\mathrm{b}}$ \\
\hline
\end{tabular}

Values with different superscript are significant different $(\mathrm{P} \geq 0.05)$

\subsection{Percentage Prevalence of Bacterial Isolates from Sites $A$ and $B$}

Table 2 presents the prevalence of various types of bacteria from cement dust polluted area. It was observed that the highest type of bacterial from polluted soil was Pseudomonas species, Acinobacter baumanii, Klebsiella oxytoca, with percentage occurrence of $18.18 \%$ respectively, while the least were Clustridium species, Micrococcus species, Citrobacters pecies, Klebsiella ornithinolytica and Pantoea species, with lowest percentage occurrence of $9.09 \%$ respectively. In the non-cement dust polluted area, it was observed that Clostridium species with percentage occurrence of $17.64 \%$, was the highest, while the least were Pseudomonas species, Citrobacter species, Klebsiella ornithinolytica, Pantoea species, Acinobacter baumanii, Enterobacter cloacae, and Serratia liquefaciens, with lowest percentage occurrence of $5.88 \%$ respectively.

Table 2. Prevalence of Bacteria Isolated from Site A and B.

\begin{tabular}{lll}
\hline Prevalence\% & & \\
\hline Bacteria & Site A & Site B \\
\hline Microcccus species & 9.09 & 11.76 \\
Serratia liquefaciens & - & 5.88 \\
Clustridium species & 9.09 & 17.64 \\
Pseudomonas species & - & 5.88 \\
Cryseobacterium meningosepticum & - & 11.76 \\
Klebsiella ornithinolytica & 9.09 & 5.88 \\
Enterobacter cloacae & - & 5.88 \\
Klebsiell aoxytoca & 18.18 & 11.76 \\
Citrobacter species & 9.09 & 5.88 \\
Proteus mirabilis & - & 11.76 \\
Pantoea species & 9.09 & 5.88 \\
Acinobacter baumanii & 18.18 & 5.88 \\
Total & 100 & 100 \\
\hline
\end{tabular}

\subsection{Biochemical Characterization of Isolated Bacteria from Cement dust Polluted Soil}

Table 3 presents the the result of gram reaction and biochemical characterization of isolated bacteria from cement dust polluted soil. It was observed that, Micrococcus species Citrobacter koseri, Pantoea species and Clustridium species 
tested positive to citrate, indole and catalase, while all the bacterial tested negative to gas production except Citrobacter koseri, Pantoea species which showed positive to gas production.

\subsection{Biochemical Characterization of Isolated Bacteria from Control Soil}

Table 4 shows the biochemical characterization of some isolated bacteria from non-polluted soil in control group. It was observed that, Micrococcus species, Klebsiell aoxytoca, Clostridium species, tested positive to citrate, indole and catalase test, while Cryseobacterium meningosepticum, Enterobacter cloacae and Serratia liquefaciens showed negative to urea test, although all the bacteria showed negative to gas production.

Table 3. Gram Reaction and Biochemical Characterization of Isolated Bacteria from cement dusty Soil in (A) Surface and below Soil.

\begin{tabular}{|c|c|c|c|c|c|c|c|c|c|c|c|c|c|c|}
\hline Sample code & Gram stain & Urea & $\mathbf{M r}$ & Vp & Glu & Suc & Lac & Cit & Ind & Cat & Coag & $\mathrm{H}_{2} \mathrm{~S}$ & Gas & Identified organism \\
\hline A & -ve rod & + & + & - & - & + & + & - & - & + & - & + & - & Pseudomonas species \\
\hline B & +ve cocci & + & - & + & + & - & - & + & + & + & - & - & - & Micrococcus species \\
\hline $\mathrm{C}$ & -ve rod & + & + & - & - & + & + & + & + & + & + & - & + & Citrobacter koseri \\
\hline D & +ve cocci & - & + & - & - & + & + & - & - & + & + & - & - & Acinobacter baumanii \\
\hline $\mathrm{E}$ & -ve rod & - & + & + & + & - & - & + & + & + & + & - & + & Pantoea species \\
\hline $\mathrm{F}$ & +ve rod & + & - & + & - & + & + & + & + & + & - & + & - & Clustridium species \\
\hline G & -ve rod & + & + & - & - & + & + & + & - & + & + & + & - & Klebsiella ornithinolytica \\
\hline
\end{tabular}

KEY:- +VE = Positive, - VE $=$ Negative, Urea $=$ Urease, $\mathrm{Mr}=$ Methyl Red, Vp $=$ Vogue's Poaskauer, Glu $=$ Glucose, Suc $=$ Sucrose, Lac $=$ Lactose, Cit $=$ Citrate, Ind = Indole, Cat $=$ Catalase, Coag = Coagulase, Mot = Motility, $\mathrm{H}_{2} \mathrm{~S}=$ Hydrogen Sulfite, Gas $=$ Gas Production.

Sample codes; A - E = Top soil. $\mathrm{F}-\mathrm{H}=$ Soil below the ground.

Table 4. Gram Reaction and Biochemical Characterization of Isolated Bacteria from control Soil (B) Surface and below

\begin{tabular}{|c|c|c|c|c|c|c|c|c|c|c|c|c|c|c|}
\hline Sample code & Gram stain & Urea & $\mathbf{M r}$ & $\mathbf{V p}$ & Glu & $\overline{\text { Suc }}$ & Lac & Cit & Ind & Cat & Coag & $\mathrm{H}_{2} \mathrm{~S}$ & Gas & Identified organism \\
\hline $\mathrm{A}$ & + ve cocci & + & - & + & + & - & - & + & + & + & - & - & - & Micrococcus species \\
\hline B & -ve rod & + & + & - & - & + & + & + & + & + & + & - & - & Klebsiella oxytoca \\
\hline $\mathrm{C}$ & +ve rod & + & - & + & - & + & + & + & + & + & - & + & - & Clostridium species \\
\hline $\mathrm{D}$ & -ve rod & + & + & - & + & - & - & + & - & - & + & - & + & Proteus mirabilis \\
\hline E & +ve cocci & - & + & - & - & + & + & + & - & - & + & + & - & $\begin{array}{l}\text { Cryseobacterium } \\
\text { meningosepticum }\end{array}$ \\
\hline $\mathrm{F}$ & +ve cocci & + & - & + & + & - & - & + & + & + & - & - & - & Micrococcus species \\
\hline $\mathrm{H}$ & -ve cocci & - & + & + & - & + & + & + & - & + & + & - & - & Enterobacter cloacae \\
\hline I & -ve rod & + & + & - & - & + & + & - & - & + & - & + & - & Pseudomonas species \\
\hline $\mathrm{J}$ & +ve rod & + & - & + & - & + & + & + & + & + & - & + & - & Clostridium species \\
\hline $\mathrm{K}$ & -ve rod & + & + & - & - & + & + & + & - & + & + & + & - & Klebsiella ornithinolytica \\
\hline $\mathrm{L}$ & -ve cocci & - & + & - & - & + & + & + & - & + & - & - & - & Serratia liquefaciens \\
\hline
\end{tabular}

KEY:- +VE $=$ Positive, $-\mathrm{VE}=$ Negative, Urea $=$ Urease, $\mathrm{Mr}=$ Methyl Red, $\mathrm{Vp}=$ Vogue's Poaskauer, Glu $=$ Glucose, Suc $=$ Sucrose, Lac $=$ Lactose, Cit $=$ Citrate, Ind $=$ Indole, $\mathrm{Cat}=$ Catalase, Coag $=$ Coagulase, Mot $=$ Motility, $\mathrm{H}_{2} \mathrm{~S}=$ Hydrogen Sulfite, Gas $=$ Gas Production.

Sample codes from; $\mathrm{A}-\mathrm{G}=$ Top soil. $\mathrm{H}-\mathrm{L}=$ Soil below the ground.

\section{Discussion}

Pollutants can cause undesirable effects on all organisms and reduce their chances of survival or success. The low bacteria populations and diversity observed in the contaminated soils showed that cement dust is toxic to bacteria. Some earlier studies have also reported high mortality in both plants and animals exposed to cement dust. Toxic elements released by the burning process of cement have been implicated in a lot of health problems and deaths. [15] found heavy metals in the tissues of some rats exposed to cement dust, causing low birth rate, multi-organ injuries and deaths. The control soils (soils free of cement dust) were observed to have higher bacterial load than those from cement dust populated area, this finding is in agreement with $[16,17,18]$ who reported increase in microbial diversity and population as sample collections were moved away from the factory site. However, the report of [19] contradicts the present study. They observed high population of cultivable bacteria, about $36 \times 10^{7} \mathrm{CFU} / \mathrm{gm}$ in sewage-irrigated soil compared with the $1.74 \times 10^{6} \mathrm{CFU} / \mathrm{gm}$ of the uncontaminated soil. The high population of bacteria in the sewage-irrigated soil could be attributable to the high organic matter in the sewage.

The high bacteria densities at the soil surface compared with soils below the surface is in agreement with the findings of [20]. This could be because more nutrients and favorable conditions are at the soil surface than beneath. It could also be explained that more bacteria would aggregate at the surface, close to plant roots where they would be involved in materials decomposition, aeration, and nutrients cycling, to improve soil fertility. [21] reported that soil microorganisms densities decline as they dug progressively deep in to the soil. They said this could be because the quality and quantity of carbon substrate (organic matter) decline as we go deep in the soil. Surface soil is rich in carbon substrates from the 
input of root exudates, surface litters and root detritus.

The bacterial isolates identified in this study were mostly represented by Gram-negative bacteria which were often found in control soils, and this result is in agreement with the observation made by $[22,23,24]$. The diversity of Clustridium species in this study is high in non-contaminated soil compared with the contaminated soil. However, the diversity of Acinobacter baumanii, Pseudomonas species, and Klbsiella oxytoca were high in the contaminated soil compared with the non-contaminated soil. Similar trend was also observed in the data obtained by [25]. This observation is because species survival in the soil is control by many factors other than the presence of contaminants. [26, 27] reported that the effect of cement dust on the diversity of soil bacteria cannot be generalized, but instead is dependent on the bacterial genera, and perhaps the species. Microbial survival in polluted soils depends on intrinsic biochemical and structural properties, physiological, and/or genetic adaptation.

\section{Conclusion}

This study has established that there are less bacterial in the soil contaminated with cement dust compared with noncontaminated soil. Bacterial populations were also found more abundant on the surface of non-contaminated soil. Due to this antimicrobial activity, cement dust may reduce soil fertility, leading to poor agricultural outputs and loss of some plants. Therefore, pollution prevention and control strategies must be put in place in cement factories. Further research should be carried out by the use of molecular techniques to investigate microbial diversity in contaminated soils.

\section{References}

[1] Sundararaj, D. (2004). Microbiology of soil. Microbiology, $3^{\text {th }}$ Edition. Tata McGraw-Hill Publishing Company Limited, Mumbai.

[2] Anthoniraj, S. (2004). Microbiology of soil. Microbiology, $3^{\text {th }}$ Edition. Tata McGraw-Hill Publishing Company Limited, Mumbai.

[3] Pelczar, M. J., Chan, E.C.S., Krieg, Noel, R.(2003). Microbiology of soil. Microbiology, $5^{\text {th }}$ Edition. Tata McGraw-Hill Publishing Company Limited, New Delhi.

[4] Muthakaruppan, P. (2004). Microbiology of soil. Microbiology, $3^{\text {th }}$ Edition. Tata McGraw-Hill Publishing Company Limited, Mumbai.

[5] Carreto, L., E. Moore, M. F., Nobre, R. Wait, P. W., Riley, R. J. Sharp, and M. S. da Costa. (1996). Rubrobacterxylanophilus sp. nov., a new thermophilic species isolated from a thermally polluted effluent. Int. J. Syst. Bacteriol. 46: 460-465.

[6] Addo, M. A., Darko, E. O., Gordon, C., Nyarko, B. J. B. (2013). Contamination of soils and loss of productivity of cowpea (Vigna unguiculata) caused by cement dust pollution. International Journal of Research in Chemistry and Environment. 3(1): 272-282.
[7] Mandre, M. (1995). Physiological and biochemical responses of coniferous trees to alkaline dust impact. In M. Mandre (Ed) Dust Pollution and Forest Ecosystem, a Study of conifers in an Alkalized Environment Inst of Ecology. Publication. Tallinn, pp. 44-65.

[8] Mlitan, A. B., Alrayes, H. M., Alremally, A. M., Almedaham, A. M. Oaen, S. O., Alderwish, M. N. (2013). Toxicity of heavy metals and microbial analysis of souil samples collected from the area around Zliten cement Factory. Open Journal of Air Pollution. 2: 25-28.

[9] Laj, P., Sellegri, K. (2003). Les aerosols atmosphériques: impacts locaux, effets globaux. Revue française des Laboratoires. 349: 23-34.

[10] Ayanwale, V. A., Bala, J. (2002) Method evaluation for assessing the spatial distribution of urban soil. Journal of Environmental Quality. 31. 1576-1588.

[11] Madigon, M. T., Martinko, J. M. (2006). Biology of Microorganisms.11th Edition. Upper saddle.

[12] Krieg, N. R. and Holt, J. G. (1984). Bergey's Manual of systematic Bacteriology, Vol. 1. Williams 8. Wilkins Co., Baltimore, pp 161-172.

[13] Ogbulie, N.(1998). Characterization of the bacterial from soil. Journal of Microbiology 35: 234-238.

[14] Cheesbrough, M. Discrete Laboratory Practice in Tropic Countries Part 1, Cambridge Second Edition. Press Syndicate, University of Cambridge. 247-258 pp.

[15] Yahaya T., Okpuzor, J. and Adedayo, F. (2011). Investigation of General Effects of Cement Dust to Clear the Controversy Surrounding Its Toxicity. Asian Journal of Scientific Research, 4: $315-325$.

[16] Stanley, H. O., Odu, N. N., Immanuel, O. M. (2014). Impact of cement dust pollution on physic-chemical and microbiological properties of soil around Larfarge Cement WAPCO, Ewekoro, Southwestern Nigeria. International Journal of Advanced Biological Research. 4(4): 404-404.

[17] Kulandaivel, S., Nagarajan, S., Priyanga, A., Saravanapandian, R. and Thangarani, A. (2015). Effect of Cement Dust Pollution on Microbial Properties and Alkaline Phosphatase Enzyme Activity in Soil. International Journal of Microbiology and Applied Science. 4(2): 641-646.

[18] . Stanley, H. O., Odu, N. N. and Immanuel, O. M. (2014). Impact of cement dust pollution on physicochemical and microbiological properties of soil around Lafarge cement WAPCO, Ewekoro, Southwestern Nigeria. International Journal of Biological Research. 4(4): 400-404.

[19] Adesemoye, A. O., Opere, B. O. and Makinde, S. C. O. (2006). Microbial content of abattoir wastewater and its contaminated soil in Lagos, Nigeria. African Journal of Biotechnology 5: 1963-1968.

[20] Maier, R. M., Drees, K. P., Neilson, J. W., Henderson, D. A., Quade, J., Betancourt, J. L., Navarro- Gonzalez. R., Rainey, F. A. and McKay, C. P. (2004). Microbial life in the Atacama Desert. Science. 306: 1289-1290.

[21] Fierer, N. Schimel, J. P., Holden, P. A. (2003). Variations in microbial community composition through two soil depth profiles. Soil Biology and Biochemistry. 35: 167-176. 
[22] Trojanovska, S., Brotz, M. L. and Bhave, M. (1997). Detection of heavy metal ion resistance genes inGram-positive and Gram-negative bacteria isolated from a lead-contaminated site. Biodegradation. 8: 113-124.

[23] Brim, H., Heuer, H., Krogerrecklenfort, E., Mergeay, M. and Smalla, K. (1999). Characterization of the bacterial community of a zinc-polluted soil. Journal of Microbiology. 45: 326-338.

[24] Kelly, J. J., Haggblom, M. M., Tate, R. L. (2003). Effects of heavy metal contamination and remediation on soil microbial communities in the vicinity of a zinc smelter as indicated by analysis of microbial community phospholipid fatty acid profiles. Biology and Fertility of Soils. Vol. 38. P. 65-71.
[25] Meitz, J. A. and Sjorgen, R. E. (1983). Incidence of plasmid linked antibiotic and heavy metal resistant enterics in water sediment from agricultural and harbor sites. Water Air and Soil Pollution. 20: 147-159.

[26] Laukova, A., Marekova, M., Vasilkova, Z., Papajova, I. and Juris, P. (2002). Selected microbial consortium of raw and digested slurry and its susceptibility to enterocins. World Journal of Microbiology and Biotechnology. 18: 11-15.

[27] Malik, A., Khan, I. F. and Aleem, A. (2002). Plasmid incidence in bacteria from agricultural and industrial soils. World Journal of Microbiology and Biotechnology. 18: 827833. 